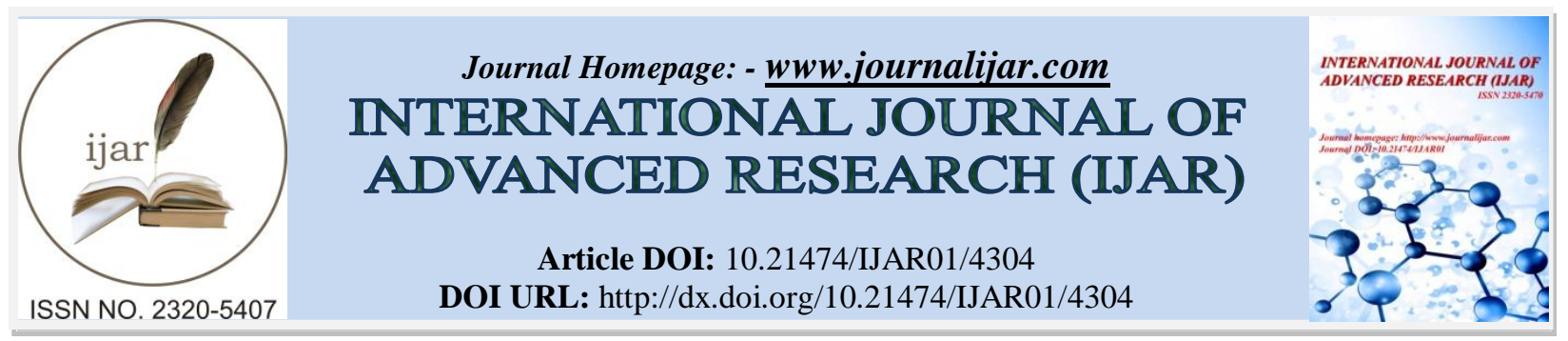

\title{
RESEARCH ARTICLE \\ DISAPPEARING DAUGHTERS AND SON PREFERENCE IN INDIA - ISSUES AND CHALLENGES IN THE PRESENT SCENARIO.
}

Dr. Pritha Dasgupta, Professor (Retd.).

Christ University, Hosur Road, Bengaluru - 560029.

\section{Manuscript Info}

Manuscript History

Received: 19 March 2017

Final Accepted: 23 April 2017

Published: May 2017

Key words:-

Patriarchal, Son preference, daughter aversion, colonial context, infanticide, high-tech-sexism, present scenario

\section{Abstract}

Sex selection is a violation of law and unethical. But our patriarchal society continues to turn a blind eye towards it or offers excuses to justify its existence. Speaking at a conference of regional Health Ministers, the then Union Minister for Health, Mr. B. Shankaranand "expressed deep concern" over the "highly unethical, unjust and immoral" practice of using amniocentesis for sex determination (Ravindra, 1986).

The practice of eliminating female foetuses is believed to be one of the main reasons for the adverse child sex ratio in the country. In this context, the present paper discusses the past and the present, the colonial encounter and efforts to eliminate this age old practice.

Despite women's increased presence in the public domain, better educational and work opportunities and changed mindset, women continue to experience physical and emotional violence both within and outside the household. Historically, the degradation of girls has been expressed in various ways. Violence against girls and women often takes the form of deprivation and neglect. But the dynamics of domestic violence can involve the control of women's reproductive capacity as well. In abusive situation, a woman may be co-erced to abort the foetus if the foetus is female. In the South Asian context the inability to produce a male heir may result in humiliation, contempt, abuse and abandonment.

Modernization and Westernization has not resulted in any change in the situation. The spread of ultrasound as well as ameniocentism for sex determination are playing a vital role in female foetus induced abortions referred to as high-tech-sexism by Amartya Sen (1990).

Copy Right, IJAR, 2017,. All rights reserved.

\section{Introduction:-}

Son preference is essentially a by-product of the ubiquitous patriarchal social system. In fact, it is illuminating to note that according to the Encyclopedia of Marriage, Divorce and Family, excavation of human burial sites suggest that infanticide was prevalent even during the earliest periods of history. The Romans and the Greeks had done away with unwanted newborn females and malformed by exposures and nearly $15-20 \%$ of all live births of that era ended in infanticide. Different Anthropological analyses too suggest that infanticide was practiced in every continent and by people at every level of cultural complexity, including our own ancestors. The practice of infanticide was in vogue even in the primitive societies (Sen, 2010). 
In view of Vibhuti Patel, In South Asia we have inherited the cultural legacy of strong son preference among all communities, religious groups and citizens of varied socio-economic background. This preference is embedded in patrilocality, patrilineage and patriarchy (Patel, 2003).

The medical journal the Lancet stated that more than 5,00,000 female foetuses are being aborted per year in India. It is clear that without sustained action on many fronts, millions more women will go missing in India. It is emerging as a silent emergency. (Ravindra, 1986).

Historically, the degradation of girls has been expressed in various ways like female infanticide. This practices though a rarity is still practiced in parts of India. As John Dahlburg points out, "In rural India, the centuries old practice can be considered a wise course of action" (Dahlburg "Where killing baby girls is no big sin", the Los Angeles Times [In the Toronto Star, February 28, 1994]. In the nearly 300 poor hamlets of Uisilampatti areas of Tamil Nadu [state] as many as 196 girls died under suspicious circumstances (Dahlburg, 1993)... Some were fed dry, unhulled rice that punctured their windpipes, or were made to swallow poisonous powdered fertilizer. Others were smothered with a wet towel, strangled or allowed to starve the death (Dahlburg, 1994).

Today, millions of female foetus is being terminated in India. This is reflected in the adverse child sex ratio of 972 girls per 1,000 boys, Amartya Sen (1990) has estimated that in the world nearly a third of girls/daughters are missing in India.

\section{The Colonial Context:-}

During the British rule, it was Duncan who first informed Lord Cornwallis that Raj Kumar Rajputs in Jaunpur destroyed their girl children. His reports show that particular communities were asking the mother to destroy their daughter by refusing nurture.

One British official, James Thomason while speaking to a group of landowners referred to one of them as son-in-law of another. His remark "raised a sarcastic laugh among them and a bystander briefly explained that he could not be a son-in-law since there was no daughters in the village". Thomason was told that the birth of a daughter was considered a tragic event and she was seldom allowed to live (Miller, 1981).

Realization of the occurrence of this practice prompted the British to prevention infanticide Act in 1870. At that juncture, there was a significantly abnormal sex ratio. Several explanations were cited - genetic predisposition of Indians towards having sons to a purposeful under reporting of women from families who distrusted British motives. Another reason cited was that male birth increases in proportion to the climate. Indian women have a high mortality rate from natural causes such as child birth. Move over the infanticide Act was difficult to enforce in a country where at that historical juncture most of the birth took place in homes and where vital registration was not commonly done.

According to Vishwanath (1999), the British adopted a three pronged strategy to suppress female infanticide in North India, these were:

1. Persuasion of the Castes known to practice female infanticide to adopt a reduced scale of dowry and wedding expenses. The strategy was tried in Punjab and Manipuri district of the North Western provinces but without much success.

2. Persuasion to give up hypergamy. This was tried among Bedi Khetris of Punjab and among Rajputs of Central Provinces. This strategy too failed.

3. Co-ercion: This was tried in the North Western Provinces and Punjab and it worked. Co-ercion took the form of close police supervision of the castes known to practice female infanticide in North Western Provinces.

Following the instructions of Lord Dalhousie a proclamation was issued in Punjab in 1853 in which it was declared that the Jagris and estates of those who continued to resort to female infanticide will be confiscated. The extent to which the proclamation was effective is evident from the close supervision. Commendable as these efforts were they were not totally successful in traditional Indian society.

Theories Based on Relative Notions of Wealth:-

Socio-economic and Socio-cultural context 
This section requires some background specific to the Indian context. There are three interrelated dimensions to socio-economic status in India: economic, political, and ritual rankings (Srinivas, 1962). Srinivas describes "high" caste or castes that have achieved a high ritual status as "Sanskritized". In Sanskritized castes, women are subordinate to men in religious rituals; they do not work outside the home (or do not leave the home in some cases); they need to be married, have male children, and have male grandchildren. They cannot initiate a divorce and they cannot remarry as widows. Parents are responsible for finding a suitable husband for their daughter, generally within the caste, and finding a husband of higher status than ones' own, a practice called hypergamy, is looked upon positively. Not being successful in arranging a marriage for one's daughter, however, reflects badly on the unmarried daughter and her family. Parents of the bride pay all marriage costs and give some dowry and/or some substantial cash payment to the family of the groom. Once married, the daughter is completely committed to the family of her husband and can no longer provide emotional, physical, or economic support to her own family, so parents can only count on male children as support for old age (Arnold, Chow, and Roy 1998; Dyson and Moore 1983). The more Sanskritized a caste and the higher one's status in the caste hierarchy (status being determined on all three axes mentioned above), the more costly it is to have a daughter instead of a son and the more barriers there are for women to integrate into the productive economy. Modern dowry (Srinivas 1989) or groomprices (Billig 1992) have become more and more common and have spread to all areas of India.

Within this context, several (interrelated) channels have been identified linking rising gender biases to rising income. A wide body of research has pointed to the persistence of son preference combined with increased availability of sex determination techniques and voluntary pregnancy terminations as largely responsible for the increasing number of "missing women" (e.g. Agnihotri 2003; Basu 1999; Das Gupta 2005; Sen 2003). It is a fact that wealth increases the ability to use such techniques but the desire to do so is a phenomenon of son-preferring households only. If son preference is shown to decrease with wealth, fewer families would practice sex selection and sex-ratios would eventually improve. The next arguments relate to the prevalence of son preference itself. Most compelling is the "prosperity effect" argument, also often loosely called "Sanskritization".4 A simplified version of the argument is that individuals in families or castes of lower ritual status who have the economic means to do so feel inclined to emulate the behavior of higher castes (Agnihotri 2000, Basu 1999, 2000; Berreman 1993; Srinivas 1962, 1989). Following from above, while ritual status (related to caste), economic status (related to wealth), and political status are different concepts that need not be related, the three axes of the hierarchy are very much intertwined. Srinivas (1962) argues that the highest possible place in the social hierarchy includes a high ranking on all three axes. A family with high ritual status will likely seek a strong economic position to reinforce its social status, and a family or a group of families that have achieved relative economic prosperity will likely seek to improve their ritual status. The "prosperity effect" implies that gender bias/son preference is likely a feature of richer households, regardless of caste. Another possible channel through which wealth can increase son preference is related to rising marriage costs (groom prices, dowries, and wedding ceremonies). Billig (1992) notes that groom prices have become common practice in the South and the amounts of money involved have risen significantly (see also Basu 1999). Anderson (2003) shows theoretically that economic development can explain increases in modern dowries in India due to the effect of wealth dispersion in a caste-based society. Higher groom prices and dowry values can cause greater son preference (or daughter aversion) since they increase the expected costs of having a daughter and the expected benefits of having a son. At the household level, this argument is not sufficient to explain why richer households would be more son-preferring, unless they are expected to spend relatively more. Given the hypergamous tradition, however, one must also take account that the expected gains from marriage may depend on one's opportunity to gain status via marriage. If wedding ceremonies are themselves used to signal social status (as argued in Bloch, Rao, and Desai 2004), higher ranked families will be expected to give grand weddings just to maintain their status while families of lower social status will incur the expense in order to gain full social benefits when their daughter marries into a family of higher status. Given that it is looked upon positively to marry upward for a girl but not for a boy, a daughter can become more valuable than a boy in terms of gaining status, as long as there are wealthier families to marry into:

"[...] families seeking social advancement compete among themselves to amass a dowry large enough to secure a place for their daughter in an elite household. This brings a prestigious alliance for parents along with prospects of well-endowed grandsons. [...] At the top of the hierarchy, however, hypergamy dooms daughters. There is no family for them to marry into." (Blaffer Hrdy 1999: 325-6). 
The problem faced by higher ranked families in this context can contribute to greater son preference, while aspiration for social advancement via marriage in lower-ranked families may explain some preference for daughters if they can afford such marriage -the caveat being related to notions of absolute wealth.

We provide an application of the value of children-approach according to which the decision to have children is made on the calculus of benefits and costs related to children. In the light of the socio-economic and socio-cultural background in India, we propose that (potential) parents' expectations of benefits and costs are biased in favour of sons.

Some causes for daughter disappearance and son preference in Modern India. There have been a number of studies highlighting the causes of son preference and 'missing girls' in India. Son preference is deeply entrenched in the social fabric of Indian society. Therefore the answer lies in the Indian Social Scenario.

\section{Value of Children Approach:-}

The value of children approach has been adopted by various scholars (Nauck 2001). Very often the cost-benefit analysis is calculated and plays an important role in determining the decision to have children. Son preference is embedded in the Psyche of the Indian parents. Benefits and costs are therefore biased in favour of the boy child. The woman is under continual pressure to produce a male child.

The aim of this paper is to contribute to the explanation of this regional pattern, which in turn implies understanding the rationale behind the son preference. We apply the revised value of children (VOC)-approach (Nauck 2001) which is grounded in the rational choice tradition. Accordingly, we argue that gender bias is caused by the sexspecific expectations of benefits and costs on the part of (potential) parents. These child-related expectations arise from the respective mix of parents' socioeconomic characteristics and the cultural setting in which they live.

\section{The Economic-Instrumental Benefit of Children:-}

Agriculture still plays an important role in India's economy. Today the agricultural sector contributes to only around 17 percent of the gross domestic product of India (Reserve Bank of India 2012: Table 3) but engages around half of the country's manpower.

Strong dependence of agrarian production on the climate and the weather implies an economically hazardous environment for a large part of the population. This is aggravated by the overall lack of public old age security and other insurance schemes covering the risks of life. As a consequence and in line with the key propositions of the VOC-approach, economic incentives to have children are prevalent in India. However, the economic-instrumental utility flow is usually in favour of sons (e.g., Cain 1986; Chen et al. 2011; Probst 2009; Vlasoff 1990).

The instrumental economic rational model is important in understanding son preference in India. Despite industrialization and globalization, agriculture remains the backbone of the Indian economy. A large portion of population is dependent on agriculture for livelihood and sustenance.

The lack of old age security and other forms of insurance lead to dependence on son. The economic instrumental value is in favour of the son who looks after the parents in old age. Girls are of less value for the parents and viewed as 'Parayadhan'. After marriage, they do not make any further contribution to the family. Indian sayings like bringing up a girl is like watering a neighbours plant despite the reality. Moreover, despite technological advancement, manual labour is still a prerequisite for agriculture and farming. In such a scenario men's contribution is more pronounced.

\section{Participation in the Economy:-}

To be more specific the widespread gender gap is slightly less in the South of India. Women's position in the rice growing region of South is slightly higher as they play a significant role in the processes of weeding and harvesting, paddy. This is in contrast to North India where men dominate. Being wheat growing region, men's muscle power is required.

\section{Regional variation in Kinship system:-}

In North India the Kinship system is based on the West Asian model which is highly patrilined and patrilocal. Daughter is viewed as an economic drain for the family. 
First, India is a patrilineal society in which patrilocal household formation is inherent (e.g., Dyson/Moore 1983; Singh 2005). Daughters are absorbed into their husband's line once they are married. Although very valuable for their husbands' family, women are of limited long-term value for their own parents. Usually the son and his family of procreation are obliged to take care of his elderly and frail parents. Second, the son's responsibility is accompanied by his higher productive potential. Having a son means a reliable source of labour in farming where manual labour is still important despite the growing spread of modern technology. Men also have greater opportunities for gainful employment since they are higher educated and qualified than women, who have gained in education and paid labour participation within the recent decades but "are still not encouraged to work outside the home" due to persisting patriarchal norms which restrict their presence in the public sphere (Singh 2005: 150). Men's superior economic status is reinforced by the dominance of patrilineal inheritance rules which ensure their ownership of productive assets like the land, farm, or the family business.

Nevertheless, regional variations can be assumed, first of all, due to the varying strength of the patrilineal kinship regime across the country. In their seminal work Dyson and Moore (1993, see also Das Gupta et al. 2003) identified two systems that meet in India and which are part of larger socio-cultural areas. The north Indian system as part of the West Asian model is very rigid as patrilineality is the rule and thus, prevailing gender discrimination is reinforced. Daughters are largely seen as an economic drain on their families. This differs from the south Indian system, which belongs to the South and East Asian kinship model. Here, the logic of patrilineality is still dominating but is more flexible. Endogamy is practiced which refers to the custom to marry within a certain (social) group similar to that of the own family.

The newly married couple usually reside separately from the husband's family (neolocality) which enables daughters to remain (physically) close to their parents after their marriage. Women may inherit and transfer property rights (Agarwal, 1988).

As a consequence both sons and daughters might render help for their families and parents in south India. This coincides with women's higher contribution to the family subsistence in the rice-growing agriculture which dominates in south India.

Women play a major role in the rice-production from weeding to harvesting. Thus, they are of relatively high economic value in contrast to central and north India where wheat production is widespread (Reserve Bank of India 2012: Table 23) and basically requires male "muscle power"(Pande/Astone 2007: 5). Economic prosperity and educational attainment are also argued to contribute to a smaller gender gap because of a lower overall economicinstrumental benefit of children. Parents gain financial independence from their offspring if their socioeconomic resources increase. On the other hand, impoverished households and low educated segments of the population depend on (minor) children's contribution to the family's living. In this respect, again, noteworthy regional differences can be observed.

In the southern states (as well as a few states in northernmost India) a great part of the population can read and write (around 80 percent) whereas literacy is much lower in the states of the northern central upland (Government of India, 2011).

A similar pattern is found for affluence: The north-central strip of India exhibits the lowest gross domestic product, embracing Uttar Pradesh with 1,586 USD per capita in 2009. This contrasts with the much higher GDP in south India, which amounted to up to 6,602 USD in Puducherry in 2009, for instance (The Economist 2012).

To summarize, the widespread gender gap in terms of the economic-instrumental benefit is assumed to be smaller in South India. Here we observe a unique setting where attenuated patrilineality, rice production, and trends of economic prosperity and educational expansion converge.

\section{Impact of Dowry:-}

The prosperity effect implies that gender bias/ son preference is likely to be a feature of rich households, regardless of caste. Wealth can lead to son preference as it is related to rising marriage costs reflect in dowries, wedding ceremonies. "The effects of the political economy of colonialism on our society can still be seen". Demands for dowries today have grown in response to the exponential increase in the value of agricultural land and urban 
property (Oldenburg, 2003). Daughter's marriages are quite costly in India across the communities. Fear of great amount of dowry makes the parents against having a girl child. They are much afraid of dowry demands.

High dowry payments used to be an upper class phenomenon but have been increasingly adopted by lower status and low caste families within the last decades (Miller 1981; Singh 2005). This trend might be triggered by the growing affluence and welfare dispersion among the Indian population which has enabled a growing share to make use of dowry as a means of increasing status and a rise in family's prestige (Anderson 2003). Even in traditional bride-price regions in south India like Tamil Nadu, a spread of dowry has been observed (Anderson 2003; Caldwell et al. 1982; Rao 1993; Singh 2005). Since in south India the preference for one child of each sex is common due to the high benefits attached to boys and girls, the growing practice of dowry started to raise concern among families about the immense financial pressures, at least after having two daughters (Diamond-Smith et al. 2008: 697).

To summarize, dowry is mandatory in north India and rural areas due to stronger patrilineality and stronger patriarchial norms and payments are argued to be highest among the upper class.

\section{Concept of Honour:-}

In addition, some of the higher castes, such as the Rajputs, are Kshatriyas which translates as warriors. These groups take great pride in their fierceness. Daughters do not fit well into their culture and are potentially a source of vulnerability in the family. Sons, on the other hand, are a source of pride and strength: "the role of sons in exerting control over farm resources, in protecting the community against dacoits, and in the army of the state... may have been factors militating for the generalized preference for sons" (Machlachlan, 1982). The Rajputs and the other warrior castes are cited throughout the literature for their liberal use of infanticide prior to the advent of sex determination techniques (Freed, 1989; Miller, 1981; Machlachlan, 1982).

The need for men as protectors may also partially explain the geographic differences in the practices of infanticide and sex selective abortion (Machlachlan, 1982). The history of Northern India, where son preference is the strongest, is characterized by numerous foreign invasions requiring the men to fight. Women did not contribute to the defense and were thus a source of weakness in the community.

\section{The present scenario:-}

Here is one of the realities that the latest census has highlighted. Although, Haryana has one of the fastest growing pecapita domestic products - it has today the lowest female male ratio. What is more, over the last ten years, it has registered the sharpest decline in the number of female children in the 0-6 age group in the country.

Pamela Philipose (2001) writes "the ultimate symbol of masculinity is the sex of the child you bear". It is reflected in home truths like "ek beta kaani, beena beta andhi, do beta sunaini". Home truths like this have a habit of escaping the confines of spoken speech and find expression in relatives of a state.

Little seems to have changed in Amritsar, Gurudaspur and Bhatinda district except the Mushrooming of sex determination clinics and the great antipathy to having baby girls. A visit to several villages of Bhatinda district reveals the antipathy of upper caste families in particular who do not want to have a girl.

Bijayalakshmi Nanda (2007) has highlighted the causes of foeticide. She categories it into socio-cultural, Economic and Political.

\section{Socio-Cultural:-}

- Preference for a son by family and society (as he carries forward the name of the family, is considered a source of support during old age and he also performs the last rites at the time of cremation).

- Social and familial pressure on women to produce sons.

- Lower status of women in the society.

- Inheritance system where a girl child has no right to her father's property.

- Social evil of dowry 


\section{Economic:-}

- Child rearing cost vis-a-vis benefits that may accrue when the child becomes an adult.

- Cost related to marriage, especially in the form of dowry.

- Most women lack financial independence.

\section{Political:-}

- The issue does not attract the attention of political parties.

- Weak enforcement of existing policies and laws aimed at curbing the practice.

- Little political interest in bringing innovative policies to deal with the problem.

\section{Conclusion:-}

The society is outlined by a strong preference for sons. Our social customs and traditions have strongly favoured male babies. A son is also considered as a source of income as an earner and also as one who brings wealth to his family at the time of marriage through dowry. The recent decline in child sex ratio is mainly due to increase in the preponderance of male babies at birth. This is attributed widespread use of medical technology for determination of the sex of the baby in the mother's womb. People need to understand that girls are the ornaments not the burden on the family. The concern regarding declining female population in India is to rise above the social domain issue to become a political, economic and reformist issue and the entire society must be sensitized.

\section{Reference:-}

1. Agarwal, Bina 1988: Who sows? Who reaps? Women and land rights in India. In: The Journal of Peasant Studies 15,4: 531-581.

2. Agnihotri, S.B. 2000. Sex Ratio Patterns in the Indian Population: A Fresh Exploration. New Delhi: Sage.

3. Agnihotri, S.B. 2003. "Survival of the Girl Child: Tunneling out of the Chakravyuha." Economic and Political Weekly October 11: 4351-560.

4. Amartya Sen, "More Than 100 Million Women Are Missing," New York Review of Books, December 20, 1990.

5. Arnold, F., M. Kim Choe, and T.K. Roy. 1998. "Son preference, the family-building process and child mortality in India." Population Studies 523: 301-15.

6. Basu, A.M. 1999. "Fertility Decline and Increasing Gender Imbalance in India, Including a Possible SouthIndian Turnaround." Development and Change 302: 237-63.

7. Basu, A.M. 2000. "Fertility Decline and Worsening Gender Bias in India: A response to S. Irudaya Rajan et al." Development and Change 31: 1093-95.

8. Berreman, G. 1993. "Sanskritization as female oppression in India." In Sex and gender hierarchies, edited by Barbara Diane Miller. Cambridge: Cambridge University Press.

9. Billig, M.S. 1992. "The Marriage Squeeze and the Rise of Groomprice in India's Kerala State." Journal of Comparative Family Studies 232:197-216.

10. Blaffer Hrdy, S. 1999. Mother Nature: a History of Mothers, Infants, and Natural Selection. New York: Pantheon Books (Random House).

11. Bloch, F., V. Rao, and S. Desai. 2004. "Wedding Celebrations as Conspicuous Consumption: Signaling Social Status in Rural India." Journal of Human Resources 39(3): 675-95.

12. Caldwell, John C.; Reddy, P. Hemachandra; Caldwell, Pat 1982: The causes of demographic change in rural South India: A micro approach. In: Population and Development Review 4,4: 689-727 [doi: 10.2307/1972469].

13. Dahlburg, (1994), "Where Killing Baby Girls 'is no big sin'," The Los Angeles Times, In The Toronto Star, (February 28).

14. Das Gupta, M. 2005. "Explaining Asia's 'Missing Women': A New Look at the Data." Population and Development Review 31(3): 529-35.

15. Debarati Sen (2010). Female Foeticide, Infanticide and Child Murder: An Insight into the status of Women in India: Women in India-Problems Potentialities and Power, Mitram, Kolkata.

16. Diamond-Smith, Nadia; Luke, Nancy; McGarvey, Stephen 2008: 'Too many girls, too much dowry': Son preference and daughter aversion in rural Tamil Nadu, India. In: Culture, Health \& Sexuality 10,7: 697-708

17. Dyson, T. \& Moore, M. (1983) On kinship structure, female autonomy and demographic behaviour in India, Population and Development Review, 9, pp. 35-60.

18. Dyson, T. and M. Moore. 1983. "On kinship structure, female autonomy and demographic behavior in India." Population and Development Review 91: 35-60. 
19. Government of India 2011: Census of India 2011.

20. Miller, B. 1981; The Endangered Sex: Neglect of Female Children in Rural North India. Ithaca, NY. Cornell Univ. Press p. 139.

21. Nanda, Bijayalaxmi Sex selective abortion: A syncretic feminist approach. Mainstream, 53(1), 2014(27 Dec): p.83-87.

22. Nauck, B. (2001). Del' Wert von Kindern ftir ihre Eltern: "Value of children" als spezielle Handlungstheorie des generativen Verhaltens und von Generationenbeziehungen im interkulturellen Vergleich [The value of children for their parents: A special action theory of fertility behavior and intergenerational relationships in crosscultural comparison]. Kdlner Zeitschrijt fiir Soziologie und Sozialpsychologie, 53, 407-435.

23. Oldenburg, V.T. (2003). Dowry Murder: The Imperial Origins of a Cultural Crime. Oxford University Press: New Delhi.

24. Patel, V (2002). Adverse Juvenile Sex Ratio in Kerala. Economic and Political Weekly. 37(22), 2124-2125.

25. Patel, V. 2003. 'The Girl Child: Health Status in the Post Independence Period', The National Medical Journal of India, AIIMS- Delhi, Vol.16, Supplement 2, pp. 42-45

26. Rao, Vijayendra 1993: The rising price of husbands: A hedonic analysis of dowry increases in rural India. In: Journal of Political Economy 101,4: 666-677.

27. Ravindra R.P (1986). 'Sex Determination' : The Scarcer Half - A report on amniocentesis and Other Sexdetermination techniques, Sex preselection and new reproductive technologies, Centre for Education and Documentation, Bombay.

28. Reserve Bank of India 2012: Handbook of Statistics on the Indian Economics. Mumbai: India Printing Works.

29. Sen, A.K. 2003. "Missing Women Revisited." British Medical Journal 327(7427): 1297-98.

30. Singh, J. P. 2005: The contemporary Indian family. In: Adams, Bernd N.; Trost, Jan (Eds.): Handbook of world families. Thousand Oaks, California: Sage Publications: 129-166

31. Srinivas, M. N. (1962). Caste in India and other essays. Bombay, India: Asia Publishing House.

32. Srinivas, M. N.1989. The Cohesive Role of Sanskritization and Other Essays. Delhi: Oxford University Press.

33. The Economist 2012 [URL: hhtp://www.economist.com/content/indian-summary, 30. April 2014].

34. Vishwanath.L.S(1999). Use of Sacred Texts-Generation of Knowledge and effort of the Colonial State of Suppress Female Infanticide in India, The Resources of History-Tradition, Narration and Nation in South Asia, École française d'Extrême - Orient Institute française de, Pondicherry. 